\title{
The Effect of Economic Freedom on National Competitiveness: Causality from a Panel of Countries
}

\author{
Tomas Verner
}

\begin{abstract}
The paper deals with economic freedom and its effect on national competitiveness. There are two goals examined within the paper. At first, I examine if economic freedom causes national competitiveness by means of the Granger causality test. Secondly, the effect of economic freedom on national competitiveness is tested using panel data for the period 2004-2011. Three groups of countries were selected: economic free, Visegrad four and repressed countries. Economic freedom and national competitiveness are quantified by comprehensive indicators: Index of economic freedom and Global competitiveness index. The results suggest that economic freedom causes national competitiveness in countries with higher degree of economic freedom. Positive effect on national competitiveness was found out.
\end{abstract}

Index Terms-Economic freedom, economic growth, economic recession, Granger causality, national competitiveness, panel data model.

\section{INTRODUCTION}

Competitiveness is a concept that has become one of the most used and vogue word in today's globalized world. It is very often discussed topic and lots of policy makers express serious interest about competitiveness at macroeconomic level, but such interest is not new, new is its intensity and spread [1]. Competitiveness is not only a mystic word; there are lots of experts and institutions which focus on competitiveness at macroeconomic level (or national competitiveness) and attempt to specify determinants and processes that affect national competitiveness.

Cultural norms and institutions are often believed to explain why certain countries grow and other remain poor [2] Since the time of Adam Smith, economists have pointed out that the freedom to choose and supply resources, competition in business, trade with others and secure property rights are fundamental factors for economic progress [3].

There are lots of factors that affect economic performance and national competitiveness. The relationship between used inputs and output describes production function. We know the so-called Cobb-Douglas production function. Inputs include capital (physical or human) and labor, but what about other factors, e.g. freedom or economic freedom? [4]

The main aim of this paper is to find out whether economic freedom promotes national competitiveness. Two hypotheses

Manuscript received September 1, 2013; revised November 8, 2013.This work was supported by the students' grant project "Seeking Factors and Barriers of the Competitiveness by using of selected Quantitative Methods". Project registration number is SGS/1/2012.

Tomas Verner is with the Department of Economics, Silesian University in Opava, School of Business Administration in Karvina, Univerzitni nam. 1934/3, 73340, Karvina, Czech Republic (e-mail: verner@opf.slu.cz). are established: I: economic freedom causes national competitiveness; II: economic freedom positively affects national competitiveness.

The paper after this part is structured as follows. Section II briefly presents national competitiveness and economic freedom; Section III deals with quantifying of these phenomena; Section IV shows examined data and methodology; Section $\mathrm{V}$ present results and section 6 concludes.

\section{NATIONAL COMPETITIVENESS AND ECONOMIC FREEDOM}

In this section I focus at competitiveness, more precisely macroeconomic or national competitiveness and phenomenon of economic freedom.

\section{A. National Competitiveness}

Applying the microeconomic approach, competitiveness can be defined as capability of a country to sell more abroad than it purchases from abroad, i.e. export performance. Reference [5] confirms trade balance and market share are insufficient indicators. Previous approach does not take into account, e.g. products quality or safety, labor conditions, standard of living or environment. Interesting attitude has [6] who likened it to a dangerous obsession. Reference [7] national competitiveness means country's ability to create, produce, distribute, and service products in international trade while earnings rising returns on its resources. However, [8] argues that the only meaningful concept of national competitiveness is national productivity. Reference [9] explains it as the long-run aim of rising standard of living and [10] extends this approach; it is an ability of an economy to secure a higher standard of living than comparable economies for the present and the future. Reference [11] summarizes that defining the competitiveness of nations is a controversial issue.

Besides, national competitiveness the increasing significance of regions in concept of European Union deserves more attention especially because of the economic efficiency of regions representing the basis of competitiveness of the country [12]. European Union defines national competitiveness like an ability to provide its citizens high and still rising standard of living and employment to all who wants to work [13]. As we can see modern approaches emphasize the standard of living and human well-being.

\section{B. Economic Freedom}

A number of researchers have dealt with the relationship between freedom and economic growth in recent years. They have explored the links between political freedom and 
economic growth [14], [15]. Economic theory indicates that economic freedom affects incentives, productive effort, and the effectiveness of resource use. Economic freedom should positively affect economic growth and national competitiveness as well [16].

Some researchers [17], [18] suggest that economic freedom may be important in explaining cross-country differences in economic performance. Other studies confirm the positive link [19], [20]. Reference [21] found that positive changes in economic freedom lead to economic growth, notwithstanding the level of economic freedom in the beginning of the growth period does not significantly contribute to explain growth. Reference [16] has constructed own indicator based on below mentioned indices. They found out greater economic freedom fosters economic growth; however the level of economic freedom is not related to growth. The similar conclusion is by [22] economic freedom (or some aspects) causes economic growth. Reference [23] argues that economic freedom, knowledge economy and global competitiveness are three of the many and very different dimensions which characterize the level of a country's performance. They found out the strong and direct link between economic freedom and national competitiveness.

\section{QUANTIFICATION OF ECONOMIC FREEDOM AND NATIONAL COMPETITIVENESS}

There are lots of possibilities to measure economic freedom and national competitiveness. I focus on some provided by international institutions.

\section{A. Measuring of Economic Freedom}

The Fraser Institute and The Heritage Foundation deal with economic freedom. The Fraser Institute by means of [24] defines economic freedom for individuals when property they acquire without the use of force, fraud, or theft is protected from physical invasions by others and they are free to use, exchange, or give their property to another as long as their actions do not violate the identical rights of others. Hence, an index of economic freedom should measure the extent to which rightly acquired property is protected and individuals are free to engage in voluntary transactions. Furthermore [25] emphasize the crucial factors of economic freedom:

- personal choice,

- voluntary exchange coordinated by markets,

- freedom to enter and compete in markets,

- protection of persons and their property from aggression by others.

The degree of economic freedom is measured in five areas [25]:

- size of government,

- legal system and property rights,

- sound money,

- freedom to trade international,

- regulation.

The Fraser Institute has published its annual report since 1996 every year.
The Heritage Foundation defines the economic freedom similarly to previous one. According to [26] is the fundamental right of every human to control his or her own labor and property. In an economically free society, individuals are free to work, produce, consume, and invest in any way they please with that freedom both protected by the state and unconstrained by the state. In economically free societies, government allows labor, capital and goods to move freely, and refrain from coercion or constraint of liberty beyond the extent necessary to protect and maintain liberty itself. The Heritage Foundation has calculated index of economic freedom and published its annual report with studies about economic freedom since 1995. Index consists of ten components:

- property rights,

- freedom from corruption,

- fiscal freedom,

- government spending,

- business freedom,

- labor freedom,

- monetary freedom,

- trade freedom,

- investment freedom,

- financial freedom,

which are grouped into four categories: (i) rule of law, (ii) limited government, (iii) regulatory efficiency and (iv) open markets (for more details see [26]). The range of the index is from 0 to 100, where 100 represent the maximum degree of economic freedom.

Countries with an index of economic freedom between:

- $0-49.9$ are repressed,

- 50 - 59.9 are mostly unfree,

- $60-69.9$ are moderately free,

- $70-79.9$ are mostly free,

- $80-100$ are free.

Lots of economists will agree with minimal incentives to economy and principles of economic. However, the key question is, what should economists suggest and policy makers do in time of economic stagnation or recession. The recent recession should be appropriate example.

\section{B. Measuring of National Competitiveness}

The International Institute for Management Development (IMD) and the World Economic Forum (WEF) are well-known international organizations dealing with national competitiveness. Both institutions provide comprehensive evaluation of national competitiveness. IMD has published World Competitiveness Yearbook since 1989. IMD ranks and analyzes the capability of economies to create and maintain an environment in which enterprises can compete [27]. National environment is divided into four main factors [27]:

- economic performance,

- government efficiency,

- business efficiency,

- infrastructure.

WEF has published Global Competitiveness Report since 1979. WEF [28] defines national competitiveness as the set of institutions, policies and factors that determine the level of 
productivity of a country. The Global Competitiveness Index ranks more than 120 countries and consists of twelve pillars [28]:

- institutions,

- infrastructure,

- macroeconomic environment,

- health and primary education,

- higher education and training,

- goods market efficiency,

- labor market efficiency,

- financial market development,

- technological readiness,

- market size,

- business sophistication,

- innovation.

It is clear that countries are in different stages of their development, therefore the will affect them in different ways. WEF [28] distinguish three stages of development:

- factor driven (pillars 1-4),

- efficiency driven (pillars 5-10),

- innovation driven (pillars 11-12).

The range of the index is from 0 to 7 , where 7 indicates the highest level of national competitiveness.

\section{DATA AND Methodology}

Used data and techniques are presented in this section.

\section{A. Data}

This section describes the data as well as the econometric methodology used in the empirical analysis. Degree of economic freedom (EF) is measured by the Heritage Foundation's Index of economic freedom; economic growth is measured by annual growth rate of real gross domestic product per capita (GDPPC). The Global Competitiveness index (GCI) was employed as a proxy variable of national competitiveness. Annual data were collected for the most economic free, Visegrad four and the less economic freedom countries 2004-2011. The less economic freedom countries are not the same as the least developed countries (LDC). LDC are situated geographically in the poverty belt and are characterized by a low economic development, a high instability, high degree of interdependence, low levels of human capital and a low level of its own resources to development [29].

GCI was standardized according to formula (1) to range 0 -10 :

$$
x^{\prime}=\frac{x_{j}-{ }_{\min } x_{j}}{\max x_{j}-{ }_{\min } x_{j}}
$$

where $x$ ' denotes the new value of GCI, $x$ initial value, ${ }_{\min } x$ the minimum value, i.e. 1 and $\max _{x} x$ the maximum value, i.e. 7.

The first group consists of Hong Kong, Singapore, Australia, New Zealand and Switzerland due to the highest average degree of economic freedom during the selected period. The countries exhibit the average high level of national competitiveness as well (see Table I).

The Visegrad four countries include Czech Republic, Hungary, Poland and Slovakia. The values of degree of economic freedom and national competitiveness are presented in Table II.

TABLE I: THE ECONOMIC FREE COUNTRIES

\begin{tabular}{lcc}
\hline \hline Countries & Economic freedom & National competitiveness \\
\hline Hong Kong & 89.6 & 71.4 \\
Singapore & 87.4 & 75.9 \\
New Zealand & 81.7 & 66.8 \\
Australia & 81.6 & 69.5 \\
Switzerland & 79.9 & 77.5 \\
\hline \hline
\end{tabular}

TABLE II: THE VISEGRAD GROUP

\begin{tabular}{lcc}
\hline \hline Countries & Economic freedom & National competitiveness \\
\hline Slovakia & 69.0 & 55.4 \\
Czech & 68.3 & 59.6 \\
Republic & 65.9 & 55.6 \\
Hungary & 61.1 & 55.5 \\
Poland &
\end{tabular}

The lowest economic freedom countries are showed in Table III.

TABLE III: THE REPRESSED COUNTRIES

\begin{tabular}{lcc}
\hline \hline Countries & Economic freedom & National competitiveness \\
\hline Syria & 49.5 & 47.7 \\
Chad & 48.1 & 29.4 \\
Venezuela & 41.9 & 41.7 \\
Libya & 37.5 & 46.7 \\
Zimbabwe & 27.8 & 33.2 \\
\hline \hline
\end{tabular}

As we can see in presented tables, group of countries with lower degree of economic freedom exhibits lower level of national competitiveness, i.e. are less competitive and vice versa.

\section{B. Methodology}

To examine the above mentioned causality and relationship I perform panel data analysis and Granger causality test. Panel data (or longitudinal data) cover both a time series and a cross-sectional dimension compared to pure time series or cross-sectional data [30]. Panel data models have become more and more popular among researchers because of their capacity for capturing the complexity of human behavior as contrasted to cross-sectional or time series data models [31].

References [31]-[33] list a number of panel data's benefits, e.g. (i) controlling for individual heterogeneity, (ii) give more informative data, more variability, less collinearity among the variables, more degrees of freedom and more efficiency, (iii) are better able to study dynamics of adjustment, (iv) are better capable to identify and measure effects that are simply not detectable in pure cross-section or pure time series data, (v) allow to construct and test more complicated behavioral models than purely cross-section or time series data and thus allow a researcher to analyze a number of important economic questions that cannot be addressed using one dimensional data, and limitations, e.g. (i) design and data collection problem, (ii) distortions of measurement errors or (iii) selectivity problem.

A panel data set is formulated by a sample that contains $N$ cross-sectional units (individuals, firms, households, 
countries etc.) that are observed at different time periods $T$ [34]. Simple linear panel data model can be written as (2):

$$
y_{i t}=\alpha+\beta X_{i t}^{\prime}+u_{i t}
$$

where $y$ represents the dependent variable, $X$ vector of explanatory variables and subscript $i$ denotes cross-section dimension (groups of countries) whereas $t$ time series dimension (2004-2011), $\alpha, \beta$ are coefficients and $u$ is a random disturbance term.

In general, three different methods can be carried out to estimate linear panel data models by means of ordinary least squares: (i) common constant refer to (2), (ii) fixed effects and (iii) random effects. The common constant method implies that there are no differences among variables of the cross-sectional dimension, so-called homogenous panel. Fixed or random effects allow us to capture the differences among units; hence the random disturbance term $u$ is given by (3):

$$
u_{i t}=\mu_{i}+v_{i t}
$$

where $\mu_{i}$ denotes unobservable individual-specific effect which is time-invariant and is responsible for any individual-specific effect that is not contained in the regression (one-way error component). The random disturbance term $u$ from (2) is sometimes expressed as so-called two-way error component (4):

$$
u_{i t}=\mu_{i}+\lambda_{t}+v_{i t}
$$

where $\lambda_{t}$ represents individual-invariant and it accounts for any time-specific effect not included in the regression. In case of fixed effect it is assumed to be fixed parameters to be estimated whereas in case of random effect it is assumed to be random and $v_{i t}$ denotes remainder disturbance which varies over individuals and time [33], [31]. But the question, which model is more appropriate still remains. For common constant and fixed effect model we can apply standard F-test under the null hypothesis $\left(\mathrm{H}_{0}\right)$ that all the constants are the same [34]. In random effect model we assume zero correlation between explanatory variables and the unobserved effect. Hausman test [35] is employed to find out if this assumption is fulfilled under $\mathrm{H}_{0}$ : random effects are consistent and efficient. Moreover, it should fulfill the assumptions for standard ordinary least squares error terms, i.e. the remained disturbance is homoskedastic, serially and spatial uncorrelated.

The Granger causality test is carried out to verify the causality between economic freedom and national competitiveness [36]. Reference [22] was followed. The key point of the Granger causality is that the future cannot cause the present or the past. However, the past may cause the present or the future. We can say that $\mathrm{X}$ is causing $\mathrm{Y}$, if we are better able to predict $\mathrm{Y}$ using all available information than if the information apart from $X$ has been used [36], [37]. If this is the case or reserved, it is causality. When $\mathrm{X}$ is causing $\mathrm{Y}$ and also $\mathrm{Y}$ is causing $\mathrm{X}$, the feedback is occurring; and when $\mathrm{X}$ is not causing $\mathrm{Y}$ and vice versa, than no causality is occurring. The Granger causality assumes stationary series only [36]. Equation (5) represents causality for variable $y$ : under $\mathrm{H}_{0}: x$ does not Granger cause $y$.

$$
\begin{aligned}
& y_{i t}=\alpha+\mu_{i}+\lambda_{t}+\sum_{j=1}^{q} \beta_{j} y_{i, t-q}+ \\
& +\sum_{j=1}^{q} \delta_{j} X_{i, t-q}+\varepsilon_{i, t}
\end{aligned}
$$

Moreover, it should fulfill the assumptions for standard ordinary least squares error terms, i.e. the remained disturbance is homoskedastic, serially and spatial uncorrelated. In particular, to avoid spurious regression, misleading conclusions and due to Granger causality test we need to find out, if the panel data are stationary or non-stationary. There are a few methods to find out the data stationary or non-stationary. For homogenous panel data we can employ [38] under the $\mathrm{H}_{0}$ : each individual time series contains unit root (non-stationary) against alternative hypothesis that each time series is stationary. Reference [39] proposes alternative approach for panel data. This method tests $\mathrm{H}_{0}$ : each individual time series contains unit root against the alternative hypothesis for at least one time series is stationary. All necessary tests are performed at the 5 per cent significance level.

\section{EMPIRICAL RESULTS}

In this section there the results of three above mentioned groups are presented.

\section{A. Granger causality}

One aim of this paper is test the hypothesis about causality (I) from economic freedom to national competitiveness. The selected groups were subjected to Granger causality test refer to (5).

TABLE IV: THE GRANGER CAUSALITY

\begin{tabular}{lcc}
\hline \hline Group of countries & Null hypothesis & Result \\
\hline Economic free & GCI does not Granger cause EF & Accepted \\
Economic free & EF does not Granger cause GCI & Rejected \\
Visegrad four & GCI does not Granger cause EF & Accepted \\
Visegrad four & EF does not Granger cause GCI & Rejected \\
Repressed & GCI does not Granger cause EF & Accepted \\
Repressed & EF does not Granger cause GCI & Accepted \\
\hline \hline
\end{tabular}

The results (Table IV) imply that higher degree of economic freedom has a causal effect on national competitiveness (Economic free and Visegrad four countries). The results for repressed countries imply that the low level of national competitiveness is not caused by low degree of economic freedom. Hypothesis I was accepted for higher degree of economic freedom countries only.

\section{B. Effect of Economic Freedom and Economic Recession}

I carried out all three models by means of least squares method including lagged explanatory variables for economic free, Visegrad four. Let us consider the following function (6) with an impact of economic recession ( $\mathrm{rec}$ ) during the selected period (2004-2011):

$$
G C I_{i t}=\alpha+\beta_{1} E F_{i t}+\beta_{2} G D P P C_{i t}+r e c+\mu_{i}+v_{i t}
$$

The fixed effect model seems to be the most appropriate 
one to identify the impact of economic freedom degree $(E F)$ and annual growth rate of GDP per capita $(G D P P C)$ on national competitiveness $(G C I)$. The results of the first two groups are shown in Table $\mathrm{V}$ (common coefficients) and Table VI (individual-specific effect).

TABLE V: THE IMPACT ON NATIONAL COMPETITIVENESS

\begin{tabular}{lcc}
\hline \hline Variable/Country's group & Economic free & Visegrad four \\
\hline Intercept & 70.54285 & 53.74256 \\
EF $(-1)$ & 0.02236 & 0.04895 \\
GDPPC (-1) & 0.04437 & 0.02861 \\
REC & -0.48568 & -0.88781 \\
\hline \hline
\end{tabular}

Numbers in parenthesis indicate the number of lags. Intercepts indicate the average level of GCI in pre-recession period: 70.54 for economic free countries and 53.74 for Visegrad four countries; rec is telling us how much the average level of GCI changed in post-recession period. The values imply that the recession effect was stronger in Visegrad countries which are less economic free and less competitive as well.

As we can see economic freedom and economic growth positively affect national competitiveness; hence the hypothesis II is accepted for economic free and Visegrad four countries.

TABLE VI: THE INDIVIDUAL EFFECT WITHIN GROUPS

\begin{tabular}{|c|c|c|c|}
\hline Economic free & Fixed effect & Visegrad countries & Fixed effect \\
\hline Hong Kong & 0.02550 & Slovakia & -1.61537 \\
\hline Singapore & 3.38767 & Czech Republic & 3.13373 \\
\hline New Zealand & -5.81089 & Hungary & -1.18839 \\
\hline Australia & -3.18047 & Poland & -0.32997 \\
\hline Switzerland & 5.57820 & - & - \\
\hline
\end{tabular}

Models and coefficients are statistically significant at five per cent significance level. The remained disturbance it (from one-way error component) fulfills the assumptions for used methods. The Maddala \& Wu test for unit root [39] was carried out and at least one of time series is stationary, thus all of panel data are stationary.

\section{CONCLUSION}

The paper dealt with economic freedom and its effect on national competitiveness. It examined two goals - causality between economic freedom and national competitiveness and effect of economic freedom on national competitiveness. Thus two hypotheses were established: I: economic freedom causes national competitiveness; II: economic freedom positively affects national competitiveness.

The degree of economic freedom was measured by the Heritage Foundation's Index of economic freedom, national competitiveness by the World Economic Forum's Global Competitiveness Index. Annual data were collected for the most economic free, Visegrad four and the less economic free countries (repressed) during the period 2004-2011. I performed panel data analysis and Granger causality test.

Empirical results imply that higher degree of economic freedom has a causal effect on national competitiveness. Thus hypothesis I was accepted for economic free and
Visegrad countries only. Economic freedom positively affected national competitiveness, hence the hypothesis II was accepted (for economic free and Visegrad countries). The degree of economic freedom promotes the national competitiveness.

\section{REFERENCES}

[1] S. Lall, "Competitiveness indices and developing countries: An economic evaluation of the Global competitiveness report," World Development, vol. 29, no. 9, pp. 1501-1525, 2001.

[2] D. S. Landes, The Wealth and Poverty of Nations: Why are Some So Rich and Others Poor, 1st ed. New York: Norton, 1998.

[3] D. C. North and R. P. Thomas, The Rise of the Western World: A New Economy History, 2nd ed. Cambridge: Cambridge University Press, 1976.

[4] J. Biddle, "The introduction of the Cobb-Douglas regression," The Journal of Economic Perspectives, vol. 26, no. 2, pp. 223-236, 2012.

[5] F. Ulengin, B. Ulengin, and S. Onsel, "A power-based measurement approach to specify macroeconomic competitiveness of countries," Socio-Economic Planning Sciences, vol. 36, pp. 203-223, 2002.

[6] P. R. Krugman, "Competitiveness: a dangerous obsession," Foreign Affairs, vol. 73, no. 2, pp. 28-44, 1994.

[7] B. R. Scott and G. C. Lodge, U.S. Competitiveness in the world economy, 1st ed. Harvard Business School Press, 1985.

[8] M. E. Porter, The Competitive Advantage of Nations: with a New Introduction, 2nd ed. New York: Free Press, 1998.

[9] A. Boltho, "The assessment: International competitiveness," Oxford Review of Economic Policy, vol. 12, no. 3, pp. 1-16, 1996.

[10] J. Fagerberg, "Technology and competitiveness," Oxford Review of Economic Policy, vol. 12, no. 3, pp. 39-51, 1996.

[11] K. Aiginger, "A framework for evaluating the dynamics competitiveness of countries," Structural Change and Economic Dynamics, no. 9, pp. 159-188, 1998.

[12] J. Nevima and J. Ramík, "Application of multicriteria decision making for evaluation of regional competitiveness," in Proc. 27th International Conference on Mathematical Methods in Economics, Prague, 2009, pp. 239-244.

[13] E. Klvačová and J. Malý, Domnělé a Skutečné Bariéry Konkurenceschopnosti EU a $\check{C} R$, 1st ed. Praha. 2008.

[14] L. Sirowy and A. Inkeles, "The effects of democracy on economic growth and inequality: a review," Studies in Comparative International Development, vol. 25, pp. 126-157, 1990.

[15] A. Przeworski and F. Limongi, "Political regimes and economic growth," Journal of Economic Perspectives, vol. 7, pp. 51-69, 1993.

[16] J. de Haan and J.-E. Sturm, "On the relationship between economic freedom and economic growth," European Journal of Political Economy, vol. 16, pp. 215-241, 2000.

[17] X. de Vansay and Z. A. Spindler, "Freedom and growth: do constitutions matter?" Public Choice, vol. 78, pp. 359-372, 1994.

[18] M. A. Nelson and R. D. Singh, "Democracy, economic freedom, fiscal policy and growth in LDCs: a fresh look," Development and Cultural Change, vol. 46, pp. 677-696, 1998.

[19] R. J. Barro, "Democracy and growth," NBER, Working paper no. 4909, 1994.

[20] J. Gwartney, R. Lawson, and R. G. Holcombe, "Economic freedom and the environment for economic growth," Journal of Institutional and Theoretical Economics, vol. 155, no. 4, pp. 1-21, 1999.

[21] L. C. Adkins, R. L. Moomaw, and A. Savvides, "Institutions, freedom and technical efficiency," Southern Economic Journal, vol. 69, pp. 92-108, 2002.

[22] M. K. Justesen, "The effect of economic freedom on growth revisited: New evidence on causality from a panel of countries 1970-1999,' European Journal of Political Economy, vol. 24, pp. 642-660, 2008.

[23] M. Herciu and C. Ogrean, "Interrelations between economic freedom, knowledge economy and global competitiveness - comparative analysis Romania and EU average," Studies in Business Economics, vol. 6, pp. 46-59, 2011.

[24] J. Gwartney, R. Lawson, and W. Block. (1996). Economic freedom of the world: 1975-1995. [Online]. Available: http://oldfraser.lexi.net/publications/books/econ_free95/.

[25] J. Gwartney, R. Lawson, J. Hall, J.-P. Chauffour, and M. D. Stroup (2011). Economic freedom of the world: 2011 annual report. [Online]. Available:

http://www.freetheworld.com/2011/reports/world/EFW2011_complet e.pdf. 
[26] T. Miller et al. (2012). 2012 Index of economic freedom, [Online]. Available:

http://www.heritage.org/index/pdf/2012/book/index_2012.pdf.

[27] IMD, World Competitiveness Yearbook 2012, 1st ed. Lausanne: IMD Press, 2011.

[28] K. Schwab et al. (2012). The global competitiveness report 2012-2013. The World Economic Forum. [Online]. Available: http://reports.weforum.org/global-competitiveness-report-2012-2013/.

[29] I. Majerová, "Global financial crisis and its impact on the least developed countries," in Proc. 13th International Conference on Finance and Banking, Karviná, 2012, pp. 216-228.

[30] J. M. Wooldridge, Econometric Analysis of Cross Section and Panel Data, 2nd ed. Massachusetts: MIT Press, 2010.

[31] C. Hsiao, Analysis of Panel Data, 2nd ed. Cambridge: Cambridge University Press, 2003

[32] N. A. Klevmarken, "Panel studies: what can we learn from them?" European Economic Review, vol. 33, no. 2-3, pp. 523-529, 1989.

[33] B. H. Baltagi, Econometric Analysis of Panel Data, 3rd ed. Chichester: John Wiley \& Sons, 2005

[34] D. Asteriou and S. G. Hall, Applied Econometrics: A modern Approach using EViews and Microfit, 2nd ed. New York: Palgrave Macmillan, 2007.

[35] J. A. Hausman, "Specification tests in econometrics," Econometrica, vol. 46, no. 6, pp. 1251-1271, 1978

[36] C. W. J. Granger, "Investigating causal relations by econometric models and cross-spectral methods," Econometrica, vol. 37, no. 3, pp. 424-438, 1969.

[37] G. S. Maddala and K. Lahiri, Introduction to Econometrics, 4th ed. Chichester: John Wiley \& Sons, 2009.
[38] A. Levin, C. Lin, and C. J. Chu, "Unit root tests in panel data: asymptotic and finite-sample properties," Journal of Econometric, no. 108, pp. 1-24, 2002.

[39] G. S. Maddala, and S. A. Wu, "Comparative study of unit root tests with panel data and a new simple test," Oxford Bulletin of Economics and Statistics, vol. 61, pp. 631-652, 1999.

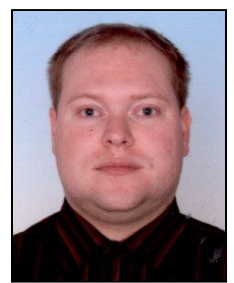

Tomas Verner was born in Sumperk in the Czech Republic on 18 December 1981. He received his MS degree in Economics at the VSB-Technical University of Ostrava, Faculty of Economics, in Ostrava, Czech Republic, in 2006. He is co-author of the book: Economic policy of the Czech Republic after its accession to the European Union (Karvina, Czech Republic, Silesian University in Opava, School of Business Administration in Karvina, 2011) and co-author of few papers, e.g. Relationship between human capital and economic growth: The case of Austria (Karvina, Czech Republic, Silesian University in Opava, School of Business Administration in Karvina, 2012), Economic performance and the labour market in the context of the economic crisis: experience from the Visegrad four countries (Liberec, Czech Republic, Technical University of Liberec, Faculty of Economics, 2012). Currently he works as a full-time Assistant Professor at the Silesian University in Opava, School of Business Administration in Karvina, Czech Republic. His research interests are related to economic policy, national competitiveness and national accounts. 